\title{
The Ghent Africa Platform, three years on: achievements and challenges [Speech delivered at the closing ceremony of GAPSYM3]
}

\author{
by Koen Goethals \\ Chief Academic Administrator, Ghent University
}

Beste leden van het Gents Afrika Platform, beste congresgangers

Het is mij een genoegen u vandaag kort te mogen toespreken. En gezien het internationale karakter van uw bijeenkomst en de herkomst van onze speciale gasten, doe ik dat beter in het Engels.

First of all I wish to welcome the representatives of the two guest institutions, the University of Nairobi and the International Centre for Reproductive Health, Fiona Mbai and our own Marleen Temmerman, the keynote speakers, Elizabeth Bukusi and Chia Longman, as well as Shirley Ardener who this morning delivered the Annual Distinguished Lecture on Africa. It is our pleasure to have you here, at Ghent University.

Furthermore, I would like to address all the people (lecturers and participants) who were involved in the workshops this afternoon. I think that your contribution as junior academics is not only an important dimension of this meeting but also a critical factor for taking the theme of this symposium seriously, that is, for working towards making future research on Africa more gender-sensitive.

In a couple of weeks, GAP will celebrate its third anniversary. From the point of view of the university authorities and equally from that of the GAP leadership, I think the past year has been a momentous one for the Ghent Africa Platform. Most importantly, from my perspective, was the fact that the University confirmed its recognition of GAP as one of its three regional or area platforms, together with the China and the India platform. In the case of GAP this recognition means that it will be awarded a fixed annual allowance in the years to come and that it will have a parttime secretary at its disposal. In that respect, it is my pleasure to announce that from 
the first of January 2010 Dominique Godfroid will spent fifty percent of her time at the GAP secretariat and the editorial office of Afrika Focus. Let me also take this occasion to thank the Department of Geography for their generosity in lending Dominique to GAP. And on a personal note, Dominique, I hope that this appointment, which is also a sign of gratitude for so many years of unpaid, voluntary work for Africa Focus, may give you new energy and courage after a very difficult year. Therefore, I have the pleasure of offering you these flowers.

In addition to the recognition it has received from the university, GAP has also obtained European recognition. Earlier this year GAP joined AEGIS as an observer member and expects full membership in the coming year. AEGIS is the Africa-Europe Group for Interdisciplinary Studies and brings together about 25 European centres of excellence which deal with Africa. Needless to say that it is a source of pride for our University that in under three years since its creation GAP has gained the respect of its European peers. Facts like these, of course have led the University authorities to confirm their financial commitment towards GAP, but what is even more important for us is the fact that GAP continues to be supported by people in different faculties and departments, and at different levels of the University and of Ghent University Association. This degree of embeddedness makes GAP special among the other regional platforms and constitutes an important aspect of its identity and profile.

Moreover, this facility to embed itself is also a function of the organisation's development and its constant renewal. A couple of days ago I was delighted to hear that recently no less than ten people, mostly junior scholars, have joined GAPs executive committee, dagelijks bestuur, which has set as its main goal of 2010 to review all the existing activities of GAP, and explore new ones whether in the domain of education, research, publication or promotion of our Africa expertise.

Also in other respects, 2010 promises to become an important year for GAP as it prepares to play a leading role in the many special events that will commemorate the independence of many African countries fifty years ago. At the level of the University, GAP together with the Open University, the people of Development Cooperation of the Department of Research Affairs, and AVRUG, will present a series of Congo lectures in the spring of next year. These lectures will present some of our finest Congo expertise to a large public of students, alumni, professionals, etc.

Moreover, GAP has taken the lead in co-organising an international conference, under the aegis of AEGIS, and together with five other Belgian partners (Egmont Institute, Royal Museum for Central Africa, KULeuven, Free University Brussels, and Bozar). This conference which is scheduled for early November (5-6th) 2010 also falls during the Belgian EU presidency which will also focus on Africa. I sincerely hope that this the necessary funding for this conference will be raised to allow the maximum participation of African institutions and scholars.

Indeed, conferences such as these which aspire to invite African partners are indeed expensive and thus, the fact that GAP has set itself the target of finding ex- 
ternal funding for organising its GAPSYMs, is a brave one. Moreover, I would like to take the opportunity to thank the two main sponsors of this event: VLIR-UOS and the Province of Eastern Flanders. Particularly the partnership with the Province illustrates how much GAP values global, African and European connections as much as local and regional ones. And this desire to establish links also runs in the other direction: the fact that the Province was willing to fund GAPSYM 3 from its Gender budget, shows how much it seeks to build bridges between regional expertise and civil society on the one hand and the University Association on the other.

I promised I was not going to keep you long. You have had a full day of conferencing and I think it is time to toast to that. So I conclude by thanking you all for your presence and participation, and by wishing GAP a prosperous 2010. 